\title{
DENSITY ASSESSMENT METHOD OF CHEMICAL COMPONENTS IN URBAN SUBMICRON AEROSOL PARTICLES
}

\author{
J. Šakalys, D. Valiulis, E. Meinorè, V. Dudoitis, K. Kvietkus, and V. Ulevičius \\ State Research Institute Center for Physical Sciences and Technology, Savanoriu 231, LT-02300 Vilnius, Lithuania \\ E-mail: ernesta.pesliakaite@gmail.com
}

Received 22 December 2014; revised 25 February 2015; accepted 20 March 2015

\begin{abstract}
During the analysis of aerosol particle density variation in urban environment it was noticed that a Quadrupole Aerosol Mass Spectrometer (Q-AMS) and a Scanning Mobility Particle Sizer (SMPS) indicated the particle diameter differently. Measurements presented in this paper were conducted in Šiauliai town from 15 March to 27 March 2012. Size distribution and concentration spectra for non-refractory submicron aerosol particles (PM1) of $\mathrm{NH}_{4}^{+}, \mathrm{NO}_{3}^{-}, \mathrm{SO}_{4}^{2-}$ and organics were obtained by using Q-AMS and SMPS. The organic particles with a diameter of up to $100 \mathrm{~nm}$ were selected for the analysis due to the considerable influence of traffic emission on the sampling site. The major formation of particles in the range of up to $100 \mathrm{~nm}$ occurs from pollutants of traffic emissions. It was observed that the density of organic aerosol particles in the range up to $100 \mathrm{~nm}$ was relatively too high if compared with the density sum of all components in the range above $100 \mathrm{~nm}$ (less than $1 \mathrm{~g} \mathrm{~cm}^{-3}$ ). This observation was opposite to the result that was expected. The latter results imply incorrectness for direct interpretation of the data obtained from Q-AMS and SMPS. Therefore, the method for evaluation of particle diameters provided by Q-AMS and SMPS is discussed in this paper.
\end{abstract}

Keywords: Q-AMS, SMPS, aerosol mass spectrometry, PM1 aerosol particles, density

PACS: 92.60.h-, 92.60.Mt, 92.60.Sz, 92.90.+x

\section{Introduction}

Science of aerosol particles was commonly acknowledged from the mid of XIX century, but nowadays we still find that there are substantial uncertainties in determination of the total effect of atmospheric aerosol particles on the global climate change and the local pollution. Nonetheless, the qualitative negative effect of aerosol particles on the air quality, their influence on the climate change and especially on human health [1-6] are accepted by all authors. Key findings of the Intergovernmental Panel on Climate Change (IPCC) [1] with a very high level of confidence confirm that the interaction between atmospheric aerosol particles and clouds is opposite to that of the greenhouse gases. However, atmospheric aerosol particles are the drivers of the climate change with a substantial portion of uncertainty for estimation of radiative forcing. The key variables which are required for further assessment of the impact of aerosol particles include, but are not limited to the aerosol size distribution, the particle shape and density, the mass concentration, the chemical composition and the myriad factors of the ambient conditions.

High mass concentration could have a lower number concentration and vice versa, hence examination of the ultrafine particle density is of high importance and is more likely to be considered when discussing the adverse effect of urban airborne particles on the human health [8].

Generally, exhaust emitted and freshly formed particles fall into the ultrafine size range and constitute $90 \%$ of the total particle volume in an urban environment [9]. A relative drop in a mean diameter due to the increased consumption of biodiesel was reported in [10]. Moreover, as reported in [11], the trend of particles being shifted towards ultrafine and nanometre size ranges results in an increase of the certain size aerosol particle density as the blending of biodiesel increases in urban areas. The net effect of particles in an urban area could be established and evaluated by assessing the implications of the particle size, chemical composition and density.

According to [9], particle density measurements can provide valuable information in order to attribute particles to the certain modes (i. e. separation into Aitken and accumulation mode) in accordance with the origin of the particles. On the other hand, the chemical composition is one of the essential factors for the particle formation along with the growth [12], in either case the density of a chemical compound within the particle has a significant implication. Therefore, the density of 
the chemical component within the particle could be acknowledged as the most important characteristic. It determines optical, chemical and mechanical properties of aerosol particles, and therefore the sedimentation rate by altering the aerodynamic diameter of the particles. The density of a certain chemical compound is a complex, time-dependent characteristic which is influenced by the aerosol particle chemical composition, chemical reactions between the particle components themselves and within the atmosphere. For example, sulfuric acid is attributed to the responsible species for the particle formation event at urban sites in several studies [13], however, recent studies imply that different species of organics are responsible for the particle growth in natural environment [14], vapours are recognized to be responsible for the change of the particle growth [15], but the role of other abundant species remains unrecognized. Moreover, the density of a chemical compound for a single aerosol particle should be taken into consideration very seriously due to the recently announced conclusions of the International Agency for Research on Cancer (IARC), which state that the outdoor air pollution is classified as carcinogenic to humans [ [6].

In general, the very first results of particle density observations were reported in [16] where low efficiency and time-consuming sample techniques of a pycnometer were used. The density of the particles varies greatly within the city campaigns in several studies. The value of the density in the range from 1.54 to $1.77 \mathrm{~g} \mathrm{~cm}^{-3}$ assuming that all particles are spherical was shown in study [17]; the range from 1.0 to $1.5 \mathrm{~g} \mathrm{~cm}^{-3}$ was reported by [18]; the effective particle density of $1.62 \pm 0.38 \mathrm{~g} \mathrm{~cm}^{-3}$ for $\mathrm{PM}_{1.8}$ and $1.67 \pm 0.37 \mathrm{~g} \mathrm{~cm}^{-3}$ for $\mathrm{PM}_{10}$ was revealed in [19], but it should be stressed that according to [20] effective densities are comparable only if the values are calculated in the same manner. It is interesting to note that the rural mode resolved particle density reported in [9] is $0.5-1.5,0.97$ and $1.5 \mathrm{~g} \mathrm{~cm}^{-3}$ for nucleation, Aitken and accumulation mode, respectively. The density of $1.36 \mathrm{~g} \mathrm{~cm}^{-3}$ was shown in [21] where the Scanning Mobility Particle Sizer (SMPS)Aerosol Mass Spectrometer (AMS) setup was used. It should be pointed out that when the SMPS-AMS setup is used, the density and the shape of the particle are crucial characteristics for derivation of the mass concentration. Nevertheless, the particles with the same mobility are likely to have distinct masses [17], hence a different density, which therefore is important for determination of the relationship between the electric mobility and the aerodynamic diameter [22, 23. The combined effect of the particle electric mobility and the shape as the effective particle density determines its mechanics [20, 21].
The main goal of this study was to examine the density distribution of submicron range (PM1) particles emitted from transport. The concentration and size distribution spectra of chemical compounds $\mathrm{NH}_{4}^{+}, \mathrm{NO}_{3}^{-}, \mathrm{SO}_{4}^{2-}$ and organics were obtained by using Q-AMS and a number of size distribution spectra of aerosol particles were obtained by using SMPS. In this paper we describe the interpretation method for density data of organic particles up to $100 \mathrm{~nm}$ obtained in parallel with Q-AMS and SMPS. The advantage of the size-density field in modeling is described as well.

\section{Experiment}

\subsection{Sampling location}

The field campaign was carried out in one of the main streets of Šiauliai town between 15 March and 27 March in 2012. Šiauliai population is over 100 thousand, and the town is situated in the North of Lithuania. The measurement instruments (Q-AMS and SMPS) were deployed at the air quality monitoring station $\left(55^{\circ} 56^{\prime} 16.11^{\prime \prime} \mathrm{N}\right.$ and $\left.23^{\circ} 18^{\prime} 29.68^{\prime \prime} \mathrm{E}\right)$. The monitoring station is under considerable influence of traffic emissions due to the location in the main street near the shopping mall.

\subsection{Instrumentation}

The Q-AMS and SMPS setup was used for data collection during the field campaign. Q-AMS provides the quantitative real-time chemical and size resolved distribution on a submicron single-particle basis for a non-refractory species such as ammonium, organics, sulfate, nitrate, and chloride. A detailed performance of Q-AMS could be found in several studies (e. g. [24], [25] and references therein). Briefly, a sample of the particles with the diameter between 10 and $100 \mathrm{~nm}$ enters through the inlet to the aerodynamic lens system [26] and is focused into a collimated beam. Consecutively the beam of the particles is flash-vaporized with a vaporizer heated up to $\sim 600^{\circ} \mathrm{C}$ and subsequently molecules are ionized by the $70 \mathrm{eV}$ electron impact, and finally ions are separated by $\mathrm{m} / \mathrm{z}$ ratio using a quadrupole mass spectrometer. The collection efficiency (CE) of Q-AMS depends on the relative humidity of the ambient air and eventually on the chemical composition of the particles. CE during the measurement was set according to the recommendation in [27] (the relative humidity of $\sim 80 \%$ together with the partial neutralization of sulfuric particles up to $\sim 55 \%$ gives a collection efficiency value of 0.5 ).

Performance of the SMPS analyzer is based on the mobility of the charged particles in an electric field. 
SMPS mainly consists of two parts: DMA (Differential Mobility Analyzer) and CPC (Condensation Particle Counter). SMPS provides a mobility diameter of the particles, which equals

$$
d=\sqrt[3]{\frac{6 m}{\pi \rho}}
$$

For the measurement campaign the SMPS model N 19.3.09 IFT/TT produced by Leibniz Institute for Tropospheric Research was employed. Its characteristics are the following: the size distribution is from 8.7 to $839.6 \mathrm{~nm}$ (Hauke medium DMA), the uncertainty of the measurement is $10 \%$, the concentration is expressed as the number of particles in $\mathrm{cm}^{3}$. More detailed information could be found in [28, 29].

Q-AMS and SMPS measure different diameters (aerodynamic and electrical mobility): $\rho d=\rho_{0} D$, where $\rho$ is the density of the particles, $\rho_{0}$ is the density of the water, $d$ is the mobility diameter of the particles, $D$ is the aerodynamic diameter measured with Q-AMS.

\subsection{Methodology}

The measurement data from 15 to 27 March 2012 were divided into two periods: the first period (the short period) was from $6 \mathrm{pm}$ on 15 March till $6 \mathrm{pm}$ on 19 March and the second period (the long period) was from 6 pm on 19 March till 3 pm on 27 March (Fig. 1). Partition was considered because concentrations of ammonium, nitrate and sulfate were higher from the beginning of the measurement till $6 \mathrm{pm}$ on 19 March and relatively lower afterwards. The concentration of chloride was neglected due to its low and widely scattered values. During the short period predominant air masses had passed over France, Germany and Northern parts of Poland, whereas during the long period air masses prevailed only from Northern or Northwest directions. Data were divided into nighttime (from $9 \mathrm{pm}$ to $3 \mathrm{am}$ ) with a relatively low impact of transport emissions and daytime (from 6 am to $9 \mathrm{pm}$ ) with intensive emissions from transport. Data of the short and long periods from nighttime and daytime were averaged. The spectra are presented in Fig. 2.
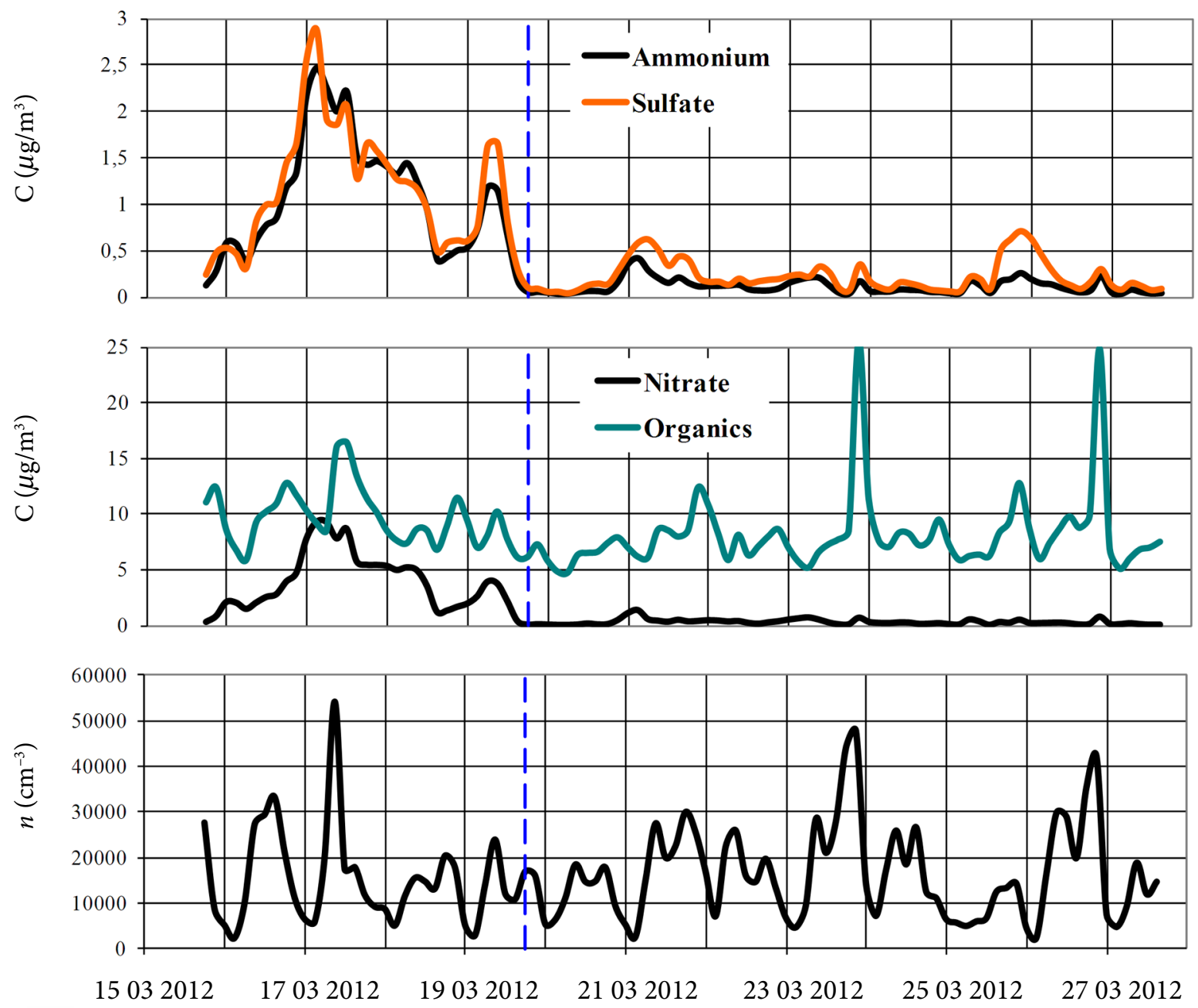

Fig. 1. The variance of $\mathrm{NH}_{4}^{+}, \mathrm{NO}_{3}^{-}, \mathrm{SO}_{4}^{2-}$, organics mass concentration and aerosol particle number concentration during the measurement campaign. 

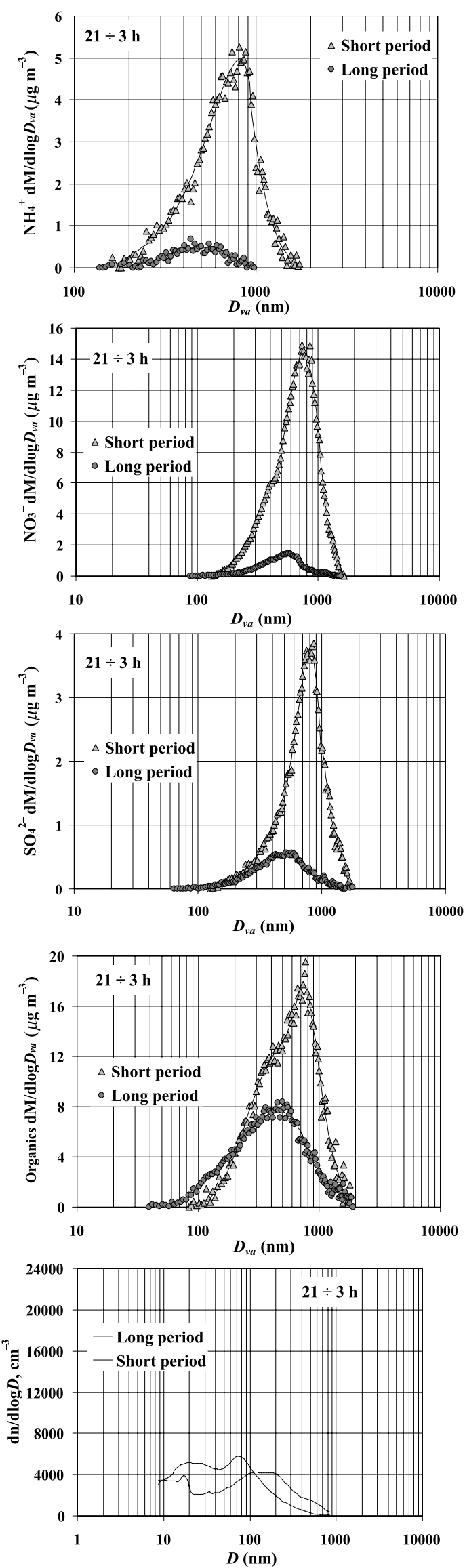
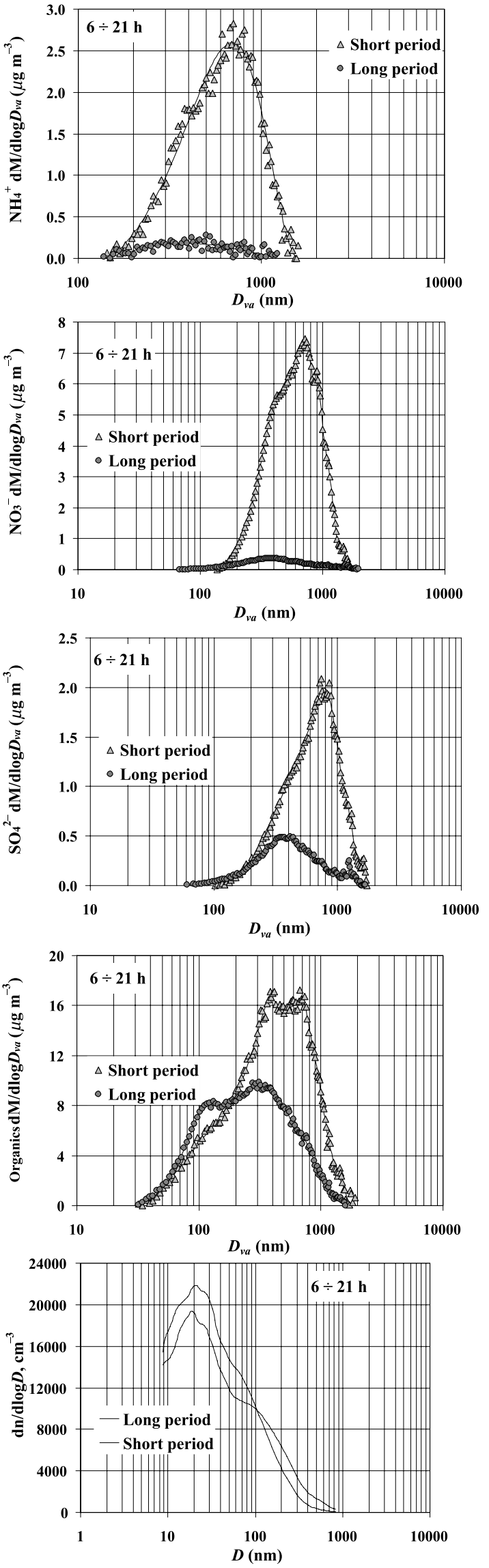

Fig. 2. Concentration of $\mathrm{NH}_{4}^{+}, \mathrm{NO}_{3}^{-}, \mathrm{SO}_{4}^{2-}$, organics and aerosol particle number during short and long periods of the measurement. 
In this paper we present an analysis of data only from the long daytime period. This period was chosen due to the lowest concentration of $\mathrm{NH}_{4}{ }^{+}, \mathrm{NO}_{3}{ }^{-}, \mathrm{SO}_{4}{ }^{2-}$ and the highest concentration of organics in the range of up to $100 \mathrm{~nm}$. The latter size range was selected particularly because particles in this range mostly consist of hydrophobic organics emission from transport and other chemical components are negligible. We assume that the main source of organics was transport emission due to the location of the measurement site. The assumption was confirmed by the level of $\mathrm{NO}_{x}$ concentration at the measurement site $\left(47.3 \pm 3.6 \mu \mathrm{g} \mathrm{m}^{-3}\right)$ and its usual background level (data from the background station in Preila $\left.1.3 \pm 0.2 \mu \mathrm{g} \mathrm{m}^{-3}\right)$. Particles with the diameter of over $100 \mathrm{~nm}$ consist of hydrophobic and hydrophilic components, furthermore they could be formed either under the influence of urban pollution or long-range transport, and hence should be aware of the humidity variation. In order to analyze particles with the diameter larger than $100 \mathrm{~nm}$ the measurements should be carried out at a background site.

\section{Results and discussion}

\subsection{Preliminary evaluation of aerosol particle density}

Q-AMS would recognize particles with the diameter $D_{v a}=\frac{\rho\left(D_{v a}\right)}{\rho_{0}} S D$ as it would have the same diameter, thus $\rho_{0} D_{v a} \approx \rho\left(D_{v a}\right) D$, where $\rho_{0}$ is the density of the water $\left(1 \mathrm{~g} \mathrm{~cm}^{-3}\right), D_{v a}$ is the particle diameter according to Q-AMS; $\rho\left(D_{v a}\right)$ is the actual particle density, $D$ is the actual particle diameter assuming that the Jayne Shape Factor $S \approx 1$ when particles are spherical [30].

In order to be able to compare aerodynamic diameters provided both by Q-AMS and SMPS, we have deducted the resultant density of the particles:

$$
\rho\left(D_{v a}\right)=\frac{\sum_{i=1}^{n} m_{i}\left(D_{v a}\right)}{\sum_{i=1}^{n} \frac{m_{i}\left(D_{v a}\right)}{\rho_{0 i}}},
$$

where $m_{i}\left(D_{v a}\right)$ is the mass of the component $i$ for particles with the diameter $D_{v a}, \rho_{0 i}$ is the material density of the component $i$.

According to $\rho\left(D_{v a}\right)$ the actual diameter of the particle can be derived as

$$
D=\frac{\rho_{0} D_{v a}}{\rho\left(D_{v a}\right)} .
$$

Q-AMS provides $\frac{\mathrm{d} m_{i}}{\mathrm{~d} \log D_{v a}}$, thus we need to make the following correction:

$$
\frac{\mathrm{d} m_{i}}{\mathrm{~d} \log D}=\frac{\mathrm{d} m_{i}}{\mathrm{~d} \log D_{v a}} \cdot \frac{\Delta \log \left(D_{v a}\right)}{\Delta \log D} .
$$

SMPS provides

$$
\frac{\mathrm{d} n}{\mathrm{~d} \log D} \text {. }
$$

By using Eqs. (4) and (5) we can express the concentration of the component $i$ for the particles with the diameter $D$ :

$$
C_{i}=\frac{\frac{\mathrm{d} m_{i}}{\mathrm{~d} \log D}}{\frac{\pi D^{3}}{6} \cdot \frac{\mathrm{d} n}{\mathrm{~d} \log D}},
$$

where $\frac{\pi D^{3}}{6}$ is the particle volume.

Here we assume that particles with the same size have the same density. Density values of $\mathrm{NH}_{4}^{+}$ $1.75 \mathrm{~g} \mathrm{~cm}^{-3}, \mathrm{NO}_{3}^{-} 1.72 \mathrm{~g} \mathrm{~cm}^{-3}, \mathrm{SO}_{4}{ }^{2-} 1.78 \mathrm{~g} \mathrm{~cm}^{-3}, \mathrm{Cl}^{-}$ $1.4 \mathrm{~g} \mathrm{~cm}^{-3}$, and organics $1.27 \mathrm{~g} \mathrm{~cm}^{-3}$ were used as the ones reported in [31].

During the experiment, the elemental carbon (EC) was not measured. For the organic carbon (OC) content evaluation literature data containing an organic mass and organic carbon (OM/OC) ratio were used [32, 33]. According to the literature data, this ratio was equal to 1.5. For the assessment of the EC content, ratio data of elemental to total carbon (EC/TC) from internal combustion engine exhaust gases were used [34], considering that TC $=\mathrm{OC}+\mathrm{EC}$. Knowing the amount of $\mathrm{OM}$ and using these relationships, the OC amount, and then the EC amount can be measured. The EC density was considered to be equal to $1.77 \mathrm{~g} \mathrm{~cm}^{-3}$ [30]. This contribution was considered extreme because the OC/EC ratio of the internal combustion engine exhaust gases was used. In the aforesaid manner, the density of $\mathrm{NO}_{3}^{-}, \mathrm{SO}_{4}{ }^{2-}$ and organics in the aerosol particle mass, including and not including EC, was deducted (Fig. 3). $\mathrm{NH}_{4}^{+}$was not analyzed due to its highly scattered values. As seen from Fig. 3 , the daytime density of organics in the range of up to $100 \mathrm{~nm}$ is relatively too high as compared with the density sum of all components in the range above $100 \mathrm{~nm}$ (less than $1 \mathrm{~g} \mathrm{~cm}^{-3}$ ). Initially it was presumed that the density for the particles with the diameter above $100 \mathrm{~nm}$ should exceed $1 \mathrm{~g} \mathrm{~cm}^{-3}$. Therefore, it is incorrect to compare aerodynamic diameters provided by Q-AMS and SMPS directly. Q-AMS and SMPS indicate the same particles differently: the mass of lower density particles is assigned to smaller particles, whereas SMPS captures the effective size. A few 

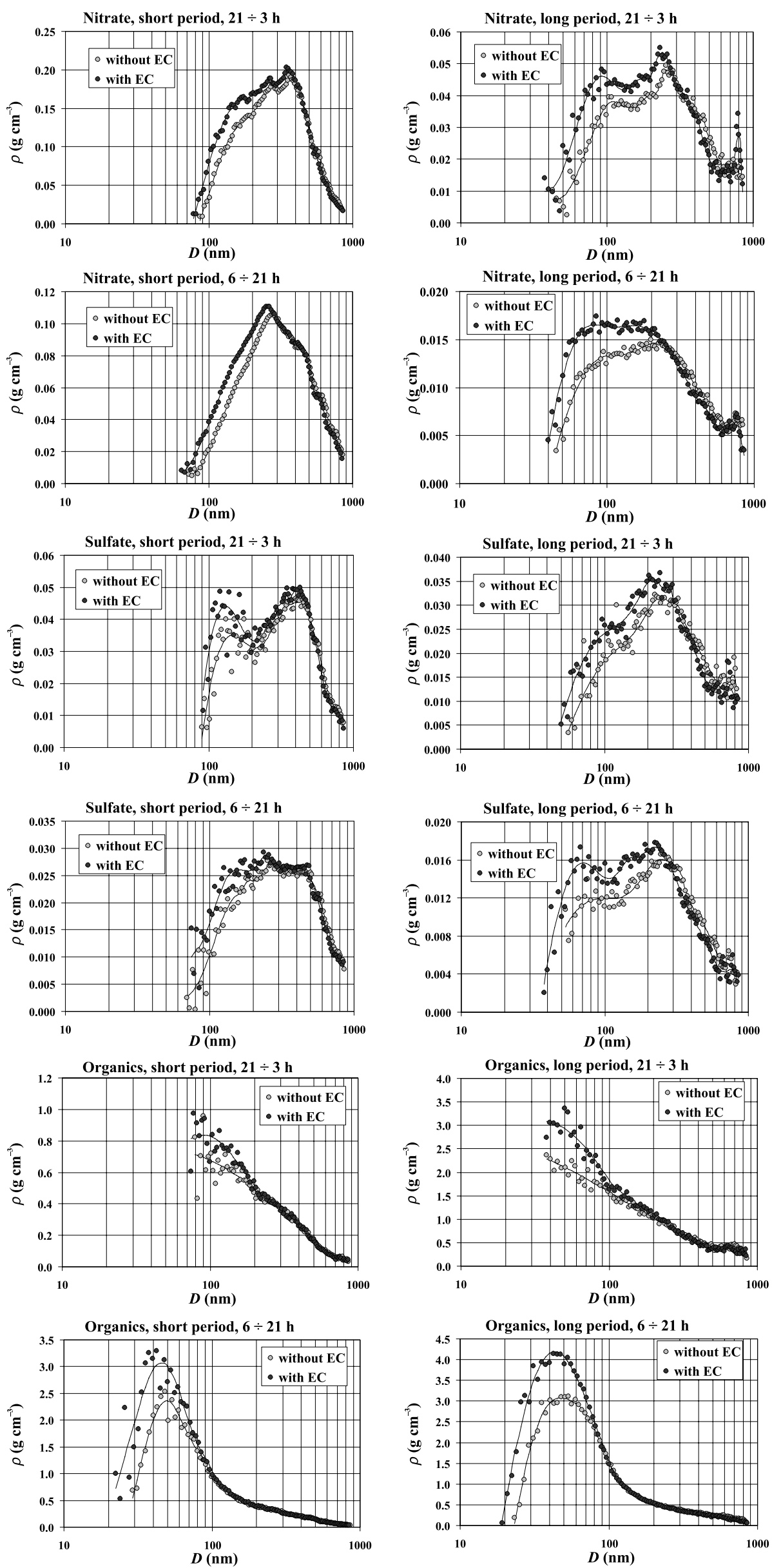

Fig. 3. $\mathrm{NO}_{3}^{-}, \mathrm{SO}_{4}^{2-}$ and organics density spectra in the aerosol particles including EC and not including EC. 
cases, when Q-AMS registers aerosol particles as of the same size, but SMPS registers them as of different size, are presented in Fig. A(a). A lower density particle mass determined with Q-AMS will be assigned to smaller particles when SMPS detects an effective particle size - larger than it will be recorded with QAMS. The density is calculated by dividing the weight by volume of the particles. Therefore, the quantity of small particulate matter with Q-AMS will be increased and the quantity of major aerosol particles will be reduced. For this reason an increased organic density for particles smaller than $100 \mathrm{~nm}$ is obtained.
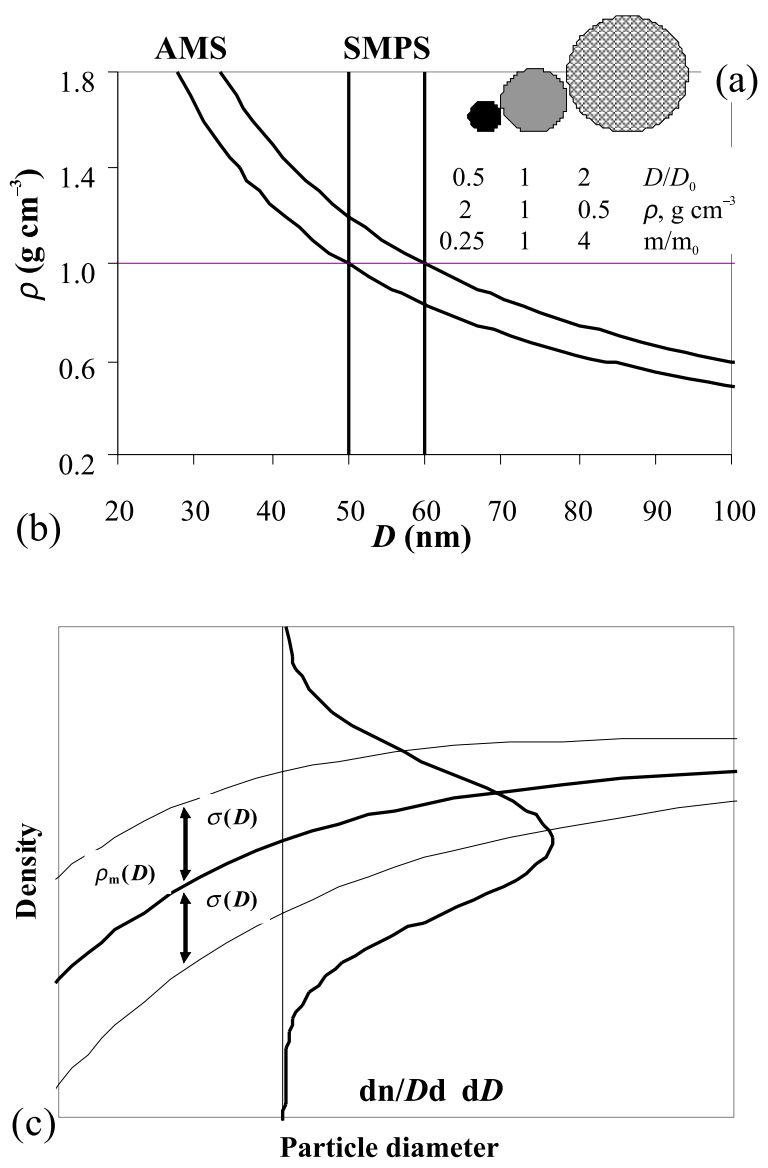

Fig. 4. (a) An example of how SMPS and Q-AMS indicate particles ( $\rho D=$ const); (b) Q-AMS and SMPS measurement range in the size-density $(\rho, D)$ graph; (c) illustration of aerosol particles distribution in the $\rho, D$ graph.

\subsection{Evaluation of aerosol particle density-size distribution}

During the evaluation of the aerosol particle density the particles of the same size were considered to be homogeneous, i. e. of equal density. In general, aerosol particles of the same size are emitted from different sources, thus the particle density may vary. Distribution of water quantities in the aerosol particles by size is unknown. The particle of the same size can be either hydrophilic or hydrophobic. During formation particles can be of different densities, especially when formation of new particles is intensive due to transport. This shows that in this way the evaluation of the particle density is erroneous. For further investigations the particle size range up to $100 \mathrm{~nm}$ (according to AMS data) was selected. Formation of the particles from pollutants of traffic emissions occurs in this range. In this range the particles are characterized by hydrophobic properties, dominated by an organic component, while there are no remaining chemical components or their amount is very little, i. e. they do not constitute a major contribution. For further analysis diurnal hours of the long period were chosen, when the traffic is intensive, and the influence of sulfate and nitrate was minimal. Figure $4(\mathrm{~b})$ shows how Q-AMS and SMPS will represent data for the particles in the range from $50 \mathrm{~nm}$ to $60 \mathrm{~nm}$ in the size-density graph.

In order to analyze the influence of the EC contribution we have considered two cases: i) all the mass of particles consists of only organics; ii) all the mass of particles consists of organics and EC. Modeling was carried out in the size-density graph field. It was presumed that all particles had a normal distribution (Fig. $4(\mathrm{c})$ ), where the median value of the aerosol particle density is

$$
\rho_{m}(D)=\rho_{m 0}\left(1-\mathrm{e}^{-\alpha D}\right),
$$

where $\rho_{\mathrm{m} 0}$ and $\alpha$ are parameters of distribution.

The standard deviation is

$$
\sigma_{D}=\sigma_{0} \mathrm{e}^{-\beta D},
$$

where $\sigma_{0}$ and $\beta$ are parameters of deviation.

The distribution is expressed by

$$
\frac{\mathrm{d} n(\rho, D)}{\mathrm{d} \rho \mathrm{d} D}=\frac{\mathrm{d} n_{\mathrm{SMPS}}}{D \mathrm{~d} \log D} \mathrm{e}^{\frac{\left(\rho-\rho_{m}(D)\right)^{2}}{2 \sigma_{D}^{2}}} .
$$

The mass of the particle was derived by using the data obtained from SMPS $\frac{\mathrm{d} n_{\text {SMPS }}}{\operatorname{d} \log D}$ for each interval $D_{1}-D_{2}$ and applying the condition $\rho D \approx$ const:

$$
M_{12}=\int_{0}^{\infty} \int_{\frac{\rho_{0} D_{1}}{D}}^{\frac{\rho_{0} D_{2}}{D}} \frac{\pi D^{3}}{6} \cdot \frac{\mathrm{d} n(\rho, D)}{\mathrm{d} \rho \mathrm{d} D} \mathrm{~d} \rho \mathrm{d} D .
$$

The derived mass was compared with the data provided by the Q-AMS in the same range. By applying 
the least squares method and varying $\rho_{m 0}, \alpha, \sigma_{0}$, and $\beta$ a solution was found when theoretically derived and experimentally obtained values coincided (Fig. 5). Table 1 presents the particle density and its standard deviation for particles with different density.

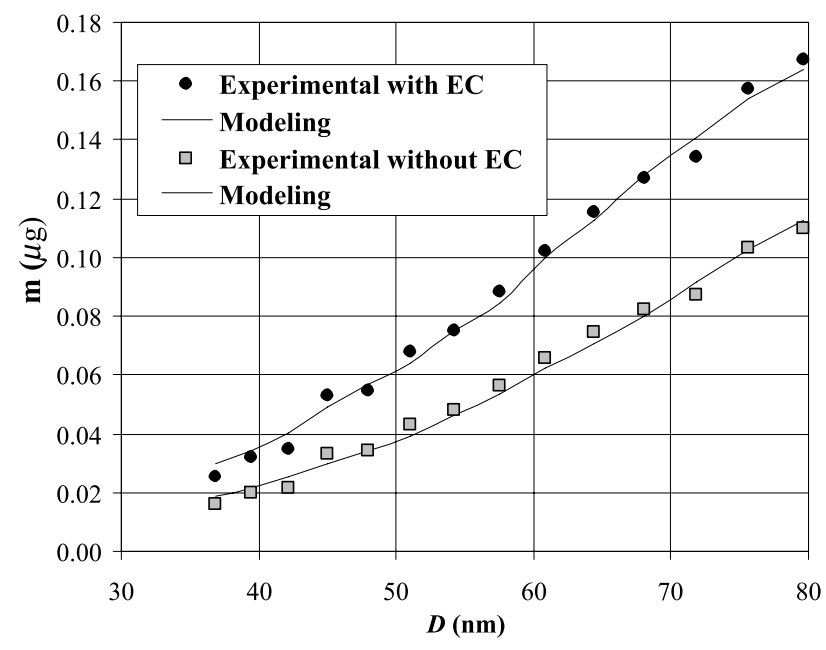

Fig. 5. Evaluation of organics mass concentration (experimental data not including EC, modeling including EC, literature data of EC used).

Aerosol particle number distribution was modeled in the $\rho, D$ graph (Fig. 6). From Table 1 and Fig. 6 we can note that the density of the smallest particles is lower than $1 \mathrm{~g} \mathrm{~cm}^{-3}$. Moreover, the median value of the density decreases, and the standard deviation is increasing with the decreasing diameter of the particles indicating that the emerging particles are porous. However, we could not accurately evaluate the contribution of $\mathrm{EC}$, thus we assume that the shown case is extreme due to the OC/EC ratio used. Therefore, the data could be considered only as indicative because they were obtained under urban conditions during the spring period, the analysis was carried out by varying 4 parameters and applying a normal distribution of density for one mode. Further experiments employing EC measurement techniques and applying the evaluation method presented in this paper could also be carried out at the

Table 1. Density and its standard deviation value of the particles with different diameters.

\begin{tabular}{c|c|c|c}
\hline$D, \mathrm{~nm}$ & 80 & 60 & 35 \\
\hline \multicolumn{4}{|c}{ without EC } \\
\hline$\rho$ & 0.68 & 0.64 & 0.54 \\
\hline$\sigma$ & 0.061 & 0.090 & 0.149 \\
\hline \multicolumn{4}{c}{ with EC } \\
\hline$\rho$ & 0.56 & 0.56 & 0.54 \\
\hline$\sigma$ & 0.010 & 0.014 & 0.024 \\
\hline
\end{tabular}
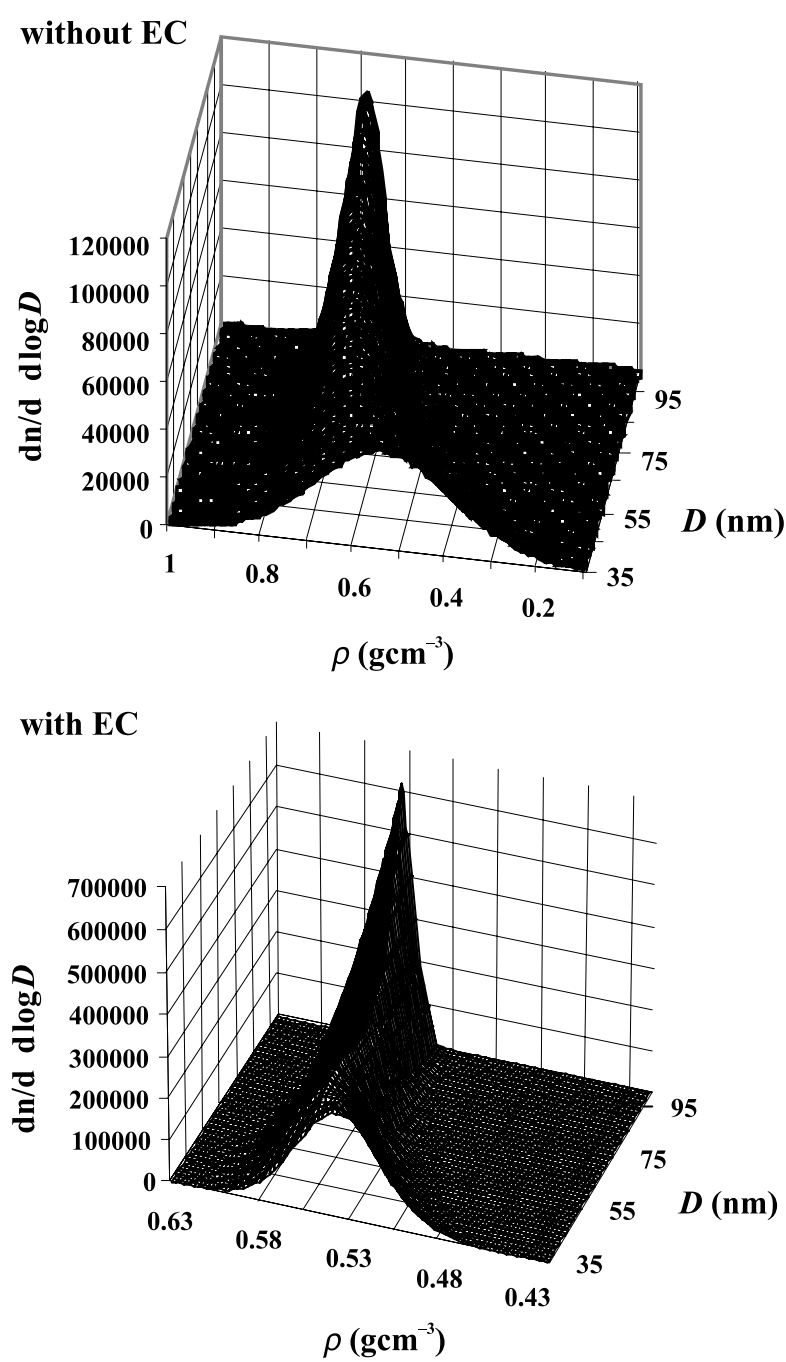

Fig. 6. Distribution of aerosol particle number concentration in the $\rho, D$ graph including EC (literature data used) and not including EC (experimental data).

background sites to check the reliability of the method. In this case, if more parameters were varied and the distribution of density for two modes was applied, we could get valuable information about the particle origin. However, this analysis showed that the advantage of the $\rho, D$ graph could be used for modeling the particle growth and coagulation.

\section{Conclusions}

Aerosol particles of the same size are porous and have different density in the urban environment during the intensive transport emission.

The density of the smallest aerosol particles $(<100 \mathrm{~nm})$ is less than $1 \mathrm{~g} \mathrm{~cm}^{-3}$ and the value of the median density decreases, whereas a standard deviation of the density increases with the decreasing diameter of the aerosol particles. 
For the data obtained by means of the Q-AMS and SMPS set up it is appropriate to model the particle distribution in the size-density $(\rho, D)$ graph.

\section{References}

[1] D.W. Dockery and C.A. Pope, Acute respiratory effects of particulate air-pollution, Annu. Rev. Publ. Health 15, 107-132 (1994).

[2] J. Ovadnevaite, K. Kvietkus, and A. Maršalka, 2002 summer fires in Lithuania: Impact on the Vilnius city air quality and the inhabitants health, Sci. Total Environ. 356(1-3), 11-21 (2006).

[3] C.A. Pope and D.W. Dockery, Health effects of fine particulate air pollution: Lines that connect, J. Air Waste Manag. Assoc. 56, 709-742 (2006).

[4] S. Solomon, D. Qin, M. Manning, Z. Chen, M. Marquis, K.B. Averyt, M. Tignor, and H.L. Miller, Climate Change 2007: The Physical Science Basis, Contribution of Working Group I to the Fourth Assessment Report of the Intergovernmental Panel on Climate Change (Cambridge University Press, Cambridge, United Kingdom and New York, NY, USA, 2007), http://www.ipcc.ch/publications and data/publications ipcc fourth assessment_report_wg1_report_the_physical_science_basis.htm, accessed: July 2014.

[5] C.P. Chio and C.M. Liao, Assessment of atmospheric ultrafine carbon particle induced human health risk based on surface area dosimetry, Atmos. Environ. 42, 8575-8584 (2008).

[6] IARC Scientific Publication No.161: Air Polution and Cancer, eds. K. Straif, A. Cohen, and J. Samet, eISBN 978-92-832-2161-6, ISSN 0300-5085 (2013).

[7] T.F. Stocker, D. Qin, G.K. Plattner, M. Tignor, S.K. llen, J. Boschung, A. Nauels, Y. Xia, V. Bex, and P.M. Midgley, Climate Change 2013: The Physical Science Basis, Contribution of Working Group I to the Fifth Assessment Report of the Intergovernmental Panel on Climate Change (Cambridge University Press, Cambridge, United Kingdom and New York, NY, USA, 2013), http://www.climatechange2013. org/report/full-report/, accessed: June 2014.

[8] X. Li, P. Gilmour, K. Donaldson, and W. MacNee, Free radical activity and proinflammatory effects of particulate air pollution $\left(\mathrm{PM}_{10}\right)$ in vivo and in vitro, Thorax 51(12), 1216-1222 (1996).

[9] J. Kannosto, A. Virtanen, M. Lemmetty, J.M. Makela, J. Keskinen, H. Junninen, T. Hussein, P. Aalto, and M. Kulmala, Mode resolved density of atmospheric aerosol particles, Atmos. Chem. Phys. 8, 5327-5227 (2008).

[10] Y.F. Lin, Y.P.G. Wu, and C.T. Chang, Combustion characteristics of waste-oil produced biodiesel/ diesel fuel blends, Fuel 86, 1772-1780 (2007).

[11] S. Chien, Y.J. Huang, S.C. Chuang, and H.H. Yang, Effects of biodiesel blending on particulate and polycyclic aromatic hydrocarbon emissions in nano/ultrafine/fine/coarse ranges from diesel engine, Aerosol Air Qual. Res. 9, 18-31 (2009).

[12] M. Kulmala, K.E.J. Lehtinen, and A. Laaksonen, Cluster activation theory as an explanation of the linear dependence between formation rate of $3 \mathrm{~nm}$ particles and sulphuric acid concentration, Atmos. Chem. Phys. 6, 787-793 (2006).

[13] D. Brus, K. Neitola, A.P. Hyvarinen, T. Petaja, J. Vanhanen, M. Sipila, P. Paasonen, M. Kulmala, and $\mathrm{H}$. Lihavainen, Homogenous nucleation of sulfuric acid and water at close to atmospherically relevant conditions, Atmos. Chem. Phys. 11, 5277-5287 (2011).

[14]Z.D. Ristovski, T. Suni, M. Kulmala, M. Boy, N.K. Meyer, J. Duplissy, A. Turnipseed, L. Moraws$\mathrm{ka}$, and U. Baltensperger, The role of sulphates and organic vapours in growth of newly formed particles in a eucalypt forest, Atmos. Chem. Phys. 10, 2919-2926 (2010).

[15] M. Ehn, T. Petaja, H. Aufmhoff, P. Aalto, K. Hameri, F. Arnold, A. Laaksonen, and M. Kulmala, Hygroscopic properties of ultrafine aerosol particles in the boreal forest: diurnal variation, solubility and the influence of sulfuric acid, Atmos. Chem. Phys. 7, 211-222 (2007).

[16] G. Hanel and J. Thudium, Mean bulk densities of samples of dry atmospheric aerosol particles: A summary of measured data, Pure Appl. Geophys. 115(4), 799-803 (1977).

[17] P.H. McMurry, X. Wang, K. Park, and K. Ehara, The relationship between mass and mobility for atmospheric particles: a new technique for measuring particle density, Aerosol Sci. Technol. 36, 227-238 (2002).

[18] M.T. Spencer, L.G. Shields, and K.A. Prather, Simultaneous measurement of the effective density and chemical composition of ambient aerosol particles, Environ. Sci. Technol. 41(4), 1303-1309 (2007).

[19]M. Hu, J. Peng, K. Sun, D. Yue, S. Guo, A. Wiedensohler, and Z. Wu, Estimation of size-resolved ambient particle density based on the measurement of aerosol number, mass, and chemical size distribution in the winter in Beijing, Environ. Sci. Technol. 46, 9941-9947 (2012).

[20] P. DeCarlo, J. Slowik, D. Worsnop, P. Davidovits, and J. Jimenez, Particle morphology and density characterization by combined mobility and aerodynamic diameter measurements. Part 1: Theory, Aerosol Sci. Technol. 38, 1185-1205 (2004).

[21] Q.G.J. Malloy, S. Nakao, L. Qi, R. Austin, C. Stothers, H. Hagino, and D.R. Cocker, Real-time aerosol density determination utilizing a modified scanning mobility particle sizer - aerosol particle mass analyzer system, Aerosol. Sci. Technol. 43(7), 673-678 (2009).

[22] L. Morawska, G. Johnson, Z. Ristovski, and V. Agranovski, Relation between particle mass 
and number for submicrometer airborne particles, Atmos. Environ. 33(13), 1983-1990 (1999).

[23] O. Schmid, E. Karg, D.E. Hagen, P.D. Whitefield, and G.A. Ferron, On the effective density of nonspherical particles as derived from combined measurements of aerodynamic and mobility equivalent size, J. Aerosol. Sci. 38(4), 431-443 (2007).

[24] J.T. Jayne, D.C. Leard, X.F. Zhang, P. Davidovits, K.A. Smith, C.E. Kolb, and D.R. Worsnop, Development of an aerosol mass spectrometer for size and composition analysis of submicron particles, Aerosol Sci. Technol. 33, 49-70 (2000).

[25] M.R. Canagaratna, J.T. Jayne, J.L. Jimenez, J.D. Allan, M.R. Alfarra, Q. Zhang, T.B. Onasch, F. Drewnick, H. Coe, A. Middlebrook, A. Delia, L.R. Williams, A.M. Trimborn, M.J. Northway, P.F. DeCarlo, C.E. Kolb, P. Davidovits, D.R. Worsnop, Chemical and microphysical characterization of ambient aerosols with the aerodyne aerosol mass spectrometer, Mass Spectrom. Rev. 26, 185-222 (2007).

[26] P. Liu, P.J. Ziemann, D.B. Kittelson, and P.H. McMurry, Generating particle beams of controlled dimensions and divergence: I. Theory of particle motion in aerodynamic lenses and nozzle expansions, Aerosol Sci. Technol. 22, 293-313 (1995).

[27] A. Middlebrook and R. Bahreini, Applying Laboratory Collection Efficiencies to Ambient Field Data, AMS Users' Meeting 2008 (2008).

[28] S. Byčenkienè, K. Plauškaitè-Šukienè, V. Dudoitis, and V. Ulevičius, Urban background levels of particle number concentration and sources in Vilnius, Lithuania, Atmos. Res. 143, 279-292 (2014).

[29] A. Wiedensohler, W. Birmili, A. Nowak, A. Sonntag, K. Weinhold, M. Merkel, B. Wehner, T. Tuch,
S. Pfeifer, M. Fiebig, et al., Mobility particle size spectrometers: harmonization of technical standards and data structure to facilitate high quality long-term observations of atmospheric particle number size distributions, Atmos. Meas. Tech. 5, 657-685 (2012).

[30] Q. Zhang, M.R. Canagaratna, J.T. Jayne, D.R. Worsnop, and J.L. Jimenez, Time- and size-resolved chemical composition of submicron particles in Pittsburgh: Implications for aerosol sources and processes, J. Geophys. Res. 110, D07S09, http:// dx.doi.org/10.1029/2004JD004649 (2005).

[31] C. Mohr, P.F. DeCarlo, M.F. Heringa, R. Chirico, J.G. Slowik, R. Richter, C. Reche, A. Alastuey, X. Querol, R. Seco, J. Peñuelas, J.L. Jiménez, M. Crippa, R. Zimmermann, U. Baltensperger, and A.S.H. Prévôt, Identification and quantification of organic aerosol from cooking and other sources in Barcelona using aerosol mass spectrometer data, Atmos. Chem. Phys. 12, 1649-1665 (2012).

[32] L. Xing, T.M. Fu, J.J. Cao, S.C. Lee, G.H. Wang, K.F. Ho, M.C. Cheng, C.F. You, and T.J. Wang, Seasonal and spatial variability of the OM/OC mass ratios and high regional correlation between oxalic acid and zinc in Chinese urban organic aerosols, Atmos. Chem. Phys. 13, 4307-4318 (2013).

[33] B.J. Turpin and H.J. Lim, Species contributions to PM2.5 mass concentrations: Revisiting common assumptions for estimating organic mass, Aerosol Sci. Technol. 35(1), 602-610 (2001).

[34] T.H. Gan, P. Hield, B. Boere, M. Bentley, T. Cogdon, P.J. Hanhela, B. Anderson, and R. Gillett, in: Proceedings of 15th ETH Conference on Combustion Generated Nanoparticles (Zurich, Switzerland, 2011). 


\title{
MIESTO SUBMIKRONINĖS FRAKCIJOS AEROZOLIO DALELIŲ CHEMINIŲ KOMPONENČIŲ TANKIO İVERTINIMO METODAS
}

\author{
J. Šakalys, D. Valiulis, E. Meinorè, V. Dudoitis, K. Kvietkus, V. Ulevičius \\ Fiziniu ir technologijos mokslu centro Fizikos institutas, Vilnius, Lietuva
}

\begin{abstract}
Santrauka
Miestuose vienas iš pagrindinių aerozolio daleliụ šaltinių yra transportas. Formuojantis aerozolio dalelèms, vienas iš svarbiausių jų parametruc - dalelių tankis. Aerozolio dalelių formavimosi mechanizmams paaiškinti reikalingi kompleksiniai eksperimentai ir jų metu gautų duomenų apibendrinimai. Šiaulių mieste $2012 \mathrm{~m}$. kovo mèn. 15-27 d. buvo atliekami aerozolio dalelių, mažesnių nei $1 \mu \mathrm{m}$, cheminès sudeties ir skaitinès koncentracijos pasiskirstymo pagal dalelių dydžius matavimai. Matavimai atlikti kvadrupoliniu aerozolių masès spektrometru (Q-AMS) ir daleliu judrumo skenavimo sistema (SMPS).

Nuo eksperimento pradžios iki kovo mèn. $19 \mathrm{~d}$. 18 val. būdinga didesnè $\mathrm{NH}_{4}^{+}, \mathrm{NO}_{3}{ }^{-}$ir $\mathrm{SO}_{4}{ }^{2-}$ koncentracija, todèl visas eksperimento laikotarpis suskirstytas $\mathfrak{i}$ trumpaji ir ilgajj periodus (iki ir po kovo mèn. $19 \mathrm{~d}$. 18 val.). Pirmajam periodui būdinga oro masių pernaša, praeinanti virš pramoninių šiaurès Europos šalių, o likusiam periodui jau būdingos santykinai švarios oro masès iš šiaurès ir šiaurès vakarų dalies. Eksperimento duomenys kiekvienam periodui buvo suskirstyti pagal laikus: naktini (nuo 21 val. iki 3 val.), kai transporto eismas yra mažiausias, ir dienini (nuo 6 val. iki 21 val.), kai transporto eismas yra intensyviausias. Tokiu būdu visi matavimų duomenys buvo suskirstyti $\mathfrak{i}$ keturias grupes, o kiekvienos grupès duomenys suvidurkinti.

Aerozolio dalelès, kurias Q-AMS priima kaip vienodas, sieja sąlyga $\rho D=$ const, kai SMPS pateikia tikruosius dalelių dydžius. Naudojantis literatūroje pateiktomis atskirų komponenčių tankių vertèmis, iš Q-AMS duomenų buvo apskaičiuoti atstojamieji dalelių tankiai ir pagal juos pakoreguoti dalelių skersmenys. Panaudo-
\end{abstract}

jus SMPS ir koreguotus Q-AMS duomenis, suskaičiuoti cheminių komponenčiu tankiai aerozolio dalelèse. Kadangi Q-AMS elementinès anglies (EC) nematuoja, tai galimas jos įnašas buvo ịvertintas remiantis literatūros duomenimis. Toliau buvo pasirinkti du variantai - kai aerozolio dalelių masę sudaro tik organines medžiagos ir organinès medžiagos kartu su EC. Nustatytos cheminių komponenčių tankių sumos neatitiko anksčiau apskaičiuotų atstojamųų tankių. Šiam neatitikimui išaiškinti buvo išanalizuoti ilgojo periodo dalelių dydžio iki $100 \mathrm{~nm}$ dieniniai matavimo duomenys. Pasirinkimą lèmé tai, kad šiame dalelių dydžių intervale vyksta dalelių formavimasis, dalelès yra hidrofobinès, dominuoja organinès medžiagos, o likusios cheminès komponentès sudaro nežymią dalị. Taip sumodeliuotas aerozolio daleliu pasiskirstymas pagal jų tankị ir dydị dalelių tankio ir dydžių diagramos $(\rho, D)$ lauke. Varijuojant tankio medianines vertes ir standartinio nuokrypio pasiskirstymo pagal dalelių dydi parametrus, gautas eksperimentinių Q-AMS išmatuotų duomenu sutapimas su modeliavimo duomenimis. Modeliavimo rezultatai parodè, kad miesto atmosferoje, esant intensyviam transporto eismui, besiformuojančios vienodo dydžio dalelès turi skirtingus tankius. Tai rodo, kad besiformuojančios dalelès yra porètos struktūros. Aerozolio dalelių, mažesnių nei $100 \mathrm{~nm}$, tankis yra mažesnis už $1 \mathrm{~g} \mathrm{~cm}^{-3}$. Tankio medianine vertè mažèja ir standartinis tankio nuokrypis didejja mažejant dalelių skersmeniui. Derinant Q-AMS ir SMPS sistema gautus duomenis tikslinga pasinaudoti dalelių kiekių pasiskirstymo modeliavimu dalelių dydžių ir tankio diagramoje. 